Research Article

\title{
DETERMINATION OF BASE AND NON-BASE SECTORS IN BANGKA REGENCY WITH LOCATION QUOTIENT ANALYSIS METHOD
}

\author{
Darman Saputra ${ }^{1}$, Julia $^{2}$, Herdiyanti ${ }^{3}$ \\ ${ }^{1}$ Management, Bangka Belitung University, Indonesia \\ ${ }^{2}$ Accountancy, Bangka Belitung University, Indonesia \\ ${ }^{3}$ Sosiology, Bangka Belitung University, Indonesia
}

Article history:

Submission 09 October 2021

Revised 16 October 2021

Accepted 17 October 2021

*Corresponding author:

E-mail:

saputrajulia07@gmail.com

\begin{abstract}
Identification of basic sectors and sub-sectors is one of the stages for planning the expansion of strategic areas as centers of economic growth. Location Quotient analysis is needed to find out how far the level of interest in the economic sector in Bangka Regency is in utilizing the base sector or superior sector. The variable used to calculate the basic economy is from local GDP an activity that is focused on activities within the local economic structure. Gross Domestic Product (GDP) is an important indicator to understand economic conditions, especially in Bangka Regency in a certain period, both based on current prices and constant prices. The data collection process was carried out using a secondary data survey by taking data on land area and production of biopharmaceutical plant commodities, vegetable crops, rice or secondary crops, plantations and fisheries. By calculating the location quotient analysis, the base sector is obtained in every sub-district in Bangka Regency so that this result is expected to determine the investment can be carried out on target.
\end{abstract}

Keywords: Base sector, Location Quotient, GRDP, Bangka Regency

\section{Introduction}

The economy is an important element in the welfare of the population of a country. A good and growing economy has an important influence on the community, which will have a positive impact on increasing people's income and welfare. Therefore, there are also opportunities for the community to earn income through their participation in economic activities.

Economic growth will be a reference for the economy of a region. High economic growth and continues to experience a good trend is a major condition or a necessity for the continuity of economic development and improvement of welfare. In the economic development of a region, the development goals themselves will not be much different from the national development goals in general. However, the development process in the regions is much more specific and has an impact on the community (Tambunan, 2001). Economic growth describes a real impact of development policies implemented, especially in the economic and social fields of society. Without economic growth, economic development is meaningless.

\section{How to cite:}

Saputra, D., Julia, \& Herdiyanti (2021). Determination of Base and Non-Base Sectors in Bangka Regency with Location Quotient Analysis Method. Indonesian Journal of Social Science Research, 2(2), 83 - 89. doi: 10.11594/ijssr.02.02.04 
Regional economic development is a process in which local governments and their communities manage existing resources and form a partnership pattern between local governments and the private sector to create new jobs and stimulate the development of economic activities in the region (Arsyad, 2010).

Economic activities are grouped into basic activities and non-basic activities. The use of the economic base model approach is generally based on added value and employment. However, using income data (value added) is more appropriate than using employment data. This is because employment has a different weight from one another. An economic indicator that is indispensable for measuring the performance of a region's economic growth is the Gross Regional Domestic Product (GRDP).

Therefore, it is necessary to analyze the area that is the mainstay of the base sector to encourage economic growth in Bangka Regency. Planning and development of economic development can be realized in a structured manner based on the potential of the basic sectors. If viewed from the value of the regional GRDP sector, the fisheries and plantation sectors have a major role in increasing the GRDP of Bangka Regency. However, it is not certain that the fisheries and plantation sectors are the basis of Bangka Regency, because comparisons with a wider area are needed. In this case, the level of harvested production area will be taken from the area per sub-district in Bangka Regency. So that each base sector will be seen from all sub-districts in Bangka Regency.

\section{Method}

This section should describe how you are supposed to rectify the problem, what approach or what methodology you are supposed to use in your paper. This can be divided into subsections if several methods are described.

\section{Theory of Economic Base and Leading Sector}

The economic base theory is the main determining factor in economic growth in a region which is directly related to the demand for goods and services from outside the region or the magnitude of the increase in exports from the region. Economic activities can be divided into activities based on the magnitude of the increase in exports from the region. Economic activities are grouped into two, namely basic activities and non-basic activities, but only basic activities can encourage the economic growth of a region.

According to Glasson (1977, the more basic sectors in an area, the more income that area will generate, increase the demand for goods and services in the area and will also lead to an increase in the volume of the non-base sector. Therefore, the basic sector is the main driver. in the economy of a region because the base sector is directly related to external demand and the non-basic sector is related indirectly and through the base sector first.

According to Ricardson (1991) there are two sectors that explain the economic structure of a region, namely:

a. Leading Sector, is a sector that serves the domestic market and markets outside the region. This means that a region is not only able to meet the needs of its own region but can export its products to other regions.

b. Non-Leading Sector, is a sector that can only serve the regional market itself.

According to Muta'ali (2015) the criteria for leading sectors have several categories depending on how big the role of the sector is in the development of a region. The following are the criteria for the leading sectors:

1. Leading sectors that have a high growth rate.

2. Leading sectors that have relatively large employment rates.

3. Leading sectors that have high inter-sector linkages both forward and backward.

4. Leading sectors that are able to create high added value.

The existence of a leading sector will greatly assist and facilitate regional planners in preparing for regional economic development. In its development, this leading sector can experience progress as well as setbacks. It depends on the efforts that can increase the role of the leading sector. Technically, the determination of the base sector is assumed to be the leading sector. The indirect method that is often used for the calculation of determining the leading sector is the Location Quotient (LQ) method. 


\section{Location Quotient}

The simplest concept to describe the potential of the basic sector is to use the sectoral contribution index in GRDP, by looking at the size of the contribution of a particular sector to the regional economy in the aggregate. Location Quotient (LQ) analysis is an analytical method used to help determine the export capacity of the economy in a region and the degree of selfsufficiency of a sector. This analysis is also used to determine whether the economic sectors are included in basic activities or not so that it can be seen which sectors are categorized as leading sectors. The LQ calculation is used to show the comparison of each economic sector at the regional level with the economic sector whose area is one level above it.

This analysis is a combination of LQ analysis and DLQ analysis. The following is the LQ formula that will be used:

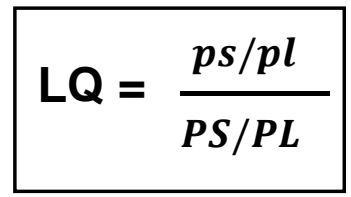

Source : Muta'ali (2015)

Information:

ps : Total production of sector $\mathrm{i}$, at local level pl : Total production amount, at local level

PS : Total production in sector $i$, at the regional level PL : Total production at the regional level The following is a description of the results of the $L Q$ analysis:

1. If $L Q>1$, this indicates that sector $i$ is the leading sector in the region. This means that the sector has an export role in the region and can be said to be a basic sector.

2. If $L Q<1$, this indicates that sector $i$ is not the leading sector in the region and does not have a role in the export sector in the region. It is said that the sector that has an $\mathrm{LQ}$ value $<1$ is a non-base sector.

3. If $L Q=1$, it means that the role of sector $i$ at the local level is equivalent to the role of sector $i$ at the regional level

Base and Non-Base Sectors
According to Arsyad (1999:116) the theory of economic basis states that the main determinants of economic growth in a region are directly related to the demand for goods and services from outside the region. The basic economic theory essentially distinguishes basic sector activities and non-base sector activities. The activity of the base sector is that the growth of the sector determines the overall development of the area, while the activity of the non-base sector is a secondary sector (city polowing) meaning that it depends on the development that occurs from the overall development.

Economic base theory seeks to find and identify the basic activities of a region, then predict that activity and analyze the additional impact of these export activities. The key concept of the basic economic theory is that exports are the engine of growth. The growth of a region is determined by how the region performs against the demand for goods and services from outside.

Furthermore, in the analysis of the economic basis theory, the theory can be used to determine potential sectors and sub-sectors in Bangka Regency based on Gross Regional Domestic Product (GRDP). If the potential sector can be developed properly, it certainly has a significant influence on the economic growth of a region, which in turn can increase regional income optimally. According to this theory, an area can be divided into mainstay and nonmainstream areas, which are further modified into potential economic sectors/sub-sectors and not potential economic sectors/sub-sectors.

\section{Results and Discussion Agriculture Sector-Biopharmaceutical Crops sub-sector}

Food crop commodities that have developed recently based on data on agricultural production of biopharmaceutical crops in Bangka Regency are Ginger, Laos/Lengkuas, Kencur and Turmeric. 
Results of LQ Analysis of Biopharmaceutical Crops Agricultural Sub-sector based on production volume per District of Bangka Regency

\begin{tabular}{lccccl}
\hline \multicolumn{1}{c}{ Districts } & Ginger & Laos & $\begin{array}{c}\text { Aromatic } \\
\text { Ginger }\end{array}$ & Turmeric & \multicolumn{1}{c}{ LQ>1 } \\
\hline Mendo barat & 0,806332 & 1,137522781 & 0,885166 & 1,178585 & Laos, Turmeric \\
Merawang & 2,162171 & 0,310980872 & 0,614872 & 0,395011 & Ginger \\
Puding Besar & 0,931339 & 0,927425397 & 1,580102 & 0,836372 & Aromatic Ginger \\
Sungailiat & 0,556384 & 0,993271395 & 1,246829 & 1,445602 & Aromatic Ginger dan Kunyit \\
Pemali & 0,526253 & 2,081726167 & 0,579308 & 0,767281 & Laos \\
Bakam & 2,663126 & 0,136213627 & 0,19124 & 0,156252 & Ginger \\
Belinyu & 1,094468 & 0,963224935 & 1,041752 & 0,890481 & Ginger, Aromatic Ginger \\
Riau Silip & 0,926858 & 0,924695938 & 1,376925 & 0,959074 & Aromatic Ginger \\
\hline
\end{tabular}

The following are the results of the analysis of the potential location of the food crop agriculture sub-sector based on indicators of production, completeness of production PS and the sub-districts that have the most number of leading commodities (LQ> 1) are Mendo Barat District, Sungailiat District and Belinyu District, which are 2 commodities. LQ $>2$ is Ginger
(Merawang), Laos / Galangal (Pemali), Ginger (Bakam).

\section{Agriculture Sector - Vegetable sub-sector}

Vegetable crop commodities that have developed recently based on data on vegetable crop production in Bangka Regency are Chili, Petai and Tomatoes.

Results of LQ Analysis of Vegetable Crops Agricultural Sub-Sector based on production volume per District of Bangka Regency

\begin{tabular}{lrrrc}
\hline \multicolumn{1}{c}{ Districts } & Chilli & \multicolumn{1}{c}{ Petai } & Tomatoes & LQ>1 \\
\hline Mendo barat & 1,229154 & 0,469313 & 0,5245 & Cabai \\
Merawang & 0,955163 & 0,826087 & 1,744898 & Tomat \\
Puding Besar & 1,445652 & 0 & 0 & Cabai \\
Sungailiat & 0,431538 & 2,830889 & 0,972281 & Petai \\
Pemali & 0,340153 & 3,537596 & 0 & Petai \\
Bakam & 0,91996 & 0 & 3,948052 & Tomat \\
Belinyu & 0,867391 & 1,850435 & 0 & Petai \\
Riau Silip & 0,889632 & 0,948941 & 1,948718 & Tomat \\
\hline
\end{tabular}

The following are the results of the analysis of the potential location of the vegetable crop agriculture sub-sector based on production indicators, completeness of production PS and the sub-districts that have the most number of leading commodities (LQ> 1) are Mendo Barat District, Merawang District, Puding Besar District, Belinyu District and Riau Silip District, namely as much as 1 commodity While commodities that have an LQ value> 2 are Petai (Sungailiat), Petai (Pemali), Tomato (Bakam).

This section describes the outputs generated in the methodology section. Elaborate and compare your results with previous research performed in the past.

\section{Agriculture Sector - Paddy and Palawija sub- sectors}

Commodities of rice and secondary crops that have developed recently based on data on agricultural production of rice and secondary crops in Bangka Regency are Rice, Rice Fields, Field Rice, Cassava, Sweet Potatoes, Peanuts, Corn and Taro. 
Saputra et al., 2021/Determination of Base and Non-Base Sectors in Bangka Regency with Location Quotient Analysis Method

Results of LQ Analysis of Rice and Palawija Agricultural Sub-Sectors based on production volume per District of Bangka Regency

\begin{tabular}{|c|c|c|c|c|c|c|c|c|c|}
\hline Districts & Paddy & $\begin{array}{c}\text { Rice } \\
\text { paddy }\end{array}$ & $\begin{array}{c}\text { Field } \\
\text { rice }\end{array}$ & Cassava & $\begin{array}{l}\text { Sweet } \\
\text { potato }\end{array}$ & Peanuts & Corn & Taro & $L Q>1$ \\
\hline $\begin{array}{l}\text { Mendo } \\
\text { barat }\end{array}$ & 1,384 & 0,669 & 1,478 & 0,704 & 1,242 & 0,700 & 1,358 & 1,524 & $\begin{array}{l}\text { Paddy, Rice } \\
\text { paddy, Sweet } \\
\text { potato, Corn, } \\
\text { and Taro }\end{array}$ \\
\hline Merawang & 0,674 & 0,264 & 0,178 & 0,645 & 9,876 & 6,161 & 3,346 & 4,351 & $\begin{array}{l}\text { Sweet } \\
\text { potato, } \\
\text { Peanuts, } \\
\text { Corn, and } \\
\text { Taro }\end{array}$ \\
\hline $\begin{array}{l}\text { Puding } \\
\text { Besar }\end{array}$ & 0,983 & 0,217 & 0,817 & 1,275 & 0,279 & 0,000 & 0,370 & 0,737 & Cassava \\
\hline Sungailiat & 0,023 & 5,016 & 0,000 & 1,286 & 0,494 & 1,664 & 0,193 & 0,131 & $\begin{array}{l}\text { Rice paddy, } \\
\text { Cassava, } \\
\text { Peanuts, and } \\
\text { Corn }\end{array}$ \\
\hline Pemali & 0,177 & 3,318 & 0,260 & 1,087 & 1,413 & 8,559 & 1,804 & 0,000 & $\begin{array}{l}\text { Rice paddy, } \\
\text { Cassava, } \\
\text { Sweet } \\
\text { potato, } \\
\text { Peanuts and } \\
\text { Corn }\end{array}$ \\
\hline Bakam & 1,703 & 1,127 & 2,057 & 0,606 & 0,205 & 0,971 & 0,209 & 0,272 & $\begin{array}{l}\text { Paddy, Rice } \\
\text { paddy, and } \\
\text { Field rice }\end{array}$ \\
\hline Belinyu & 0,785 & 0,000 & 0,933 & 1,192 & 1,124 & 1,670 & 1,170 & 0,800 & $\begin{array}{l}\text { Cassava, } \\
\text { Sweet } \\
\text { potato, } \\
\text { Peanuts, and } \\
\text { Corn }\end{array}$ \\
\hline Riau Silip & 0,735 & 1,004 & 0,608 & 1,231 & 0,366 & 0,752 & 1,037 & 0,484 & $\begin{array}{l}\text { Rice paddy, } \\
\text { Cassava, and } \\
\text { Corn }\end{array}$ \\
\hline
\end{tabular}

The following are the results of the analysis of the potential location of the vegetable crop agriculture sub-sector based on production indicators, completeness of production PS and the sub-districts that have the most number of leading commodities with $L Q>2$ values are Sweet Potatoes, Peanuts, Corn and Taro (Merawang), Paddy Rice (Merawang) Sungailiat),
Paddy Rice and Peanuts (Pemali) and Paddy Field (Bakam).

\section{Plantation Sector}

Plantation commodities that have developed recently based on production data in Bangka Regency are Oil Palm, Coconut, Rubber and Cocoa. 
LQ Analysis Results of Plantation Sub-Sector based on production volume per District of Bangka Regency

\begin{tabular}{lcrcrl}
\hline \multicolumn{1}{c}{ Districts } & Oil Palm & Coconut & Rubber & \multicolumn{1}{c}{ Cocoa } & \multicolumn{1}{c}{ LQ>1 } \\
\hline Mendo barat & 0,15083767 & 0,006246 & 1,697741 & 0,042995 & Rubber \\
Merawang & 1,07139966 & 0,383448 & 0,972812 & 1,180046 & Oil Palm, Cacoa \\
Puding Besar & 1,30794779 & 0,013121 & 0,815466 & 0,108386 & Oil Palm \\
Sungailiat & 0,72478606 & 21,05158 & 0,270908 & 4,8581 & Coconut, Cacoa \\
Pemali & 1,56640968 & 2,320512 & 0,503983 & 1,732115 & Oil Palm, Coconut, Cacao \\
Bakam & 2,09904214 & 0,484911 & 0,178639 & 2,366967 & Oil Palm, Cacao \\
Belinyu & 2,20077516 & 0,4904 & 0,106576 & 1,33827 & Oil Palm, Cacao \\
Riau Silip & 1,25535271 & 1,547889 & 0,768534 & 3,138909 & Oil Palm, Coconut, Cacao \\
\hline
\end{tabular}

The following are the results of the analysis of the potential location of the plantation sector based on production indicators, completeness of production PS and the sub-districts that have the most number of leading commodities with LQ>2 values are Coconut and Cocoa (Sungailiat), Coconut (Pemali), Oil Palm (Bakam) and Palm Oil (Belinyu).

\section{Capture Fisheries Sector}

Capture Fisheries Commodities that have developed recently based on production data in Bangka Regency are Marine Capture Fisheries and Mainland General Water Fisheries.

Results of LQ Fisheries Sub-Sector Analysis based on production volume per District of Bangka Regency

\begin{tabular}{lccl}
\hline \multicolumn{1}{c}{ Districts } & Fishing in the Sea & $\begin{array}{c}\text { Mainland General } \\
\text { Water Fisheries }\end{array}$ & \multicolumn{1}{c}{ LQ>1 } \\
\hline Mendo barat & 0,969186953 & 2,750266913 & Mainland General Water Fisheries \\
Merawang & 0,910094842 & 6,106863479 & Mainland General Water Fisheries \\
Puding Besar & 0,829224082 & 10,70054796 & Mainland General Water Fisheries \\
Sungailiat & 1,011439883 & 0,350182757 & Fishing in the Sea \\
Pemali & 0,950672347 & 3,801948137 & Mainland General Water Fisheries \\
Bakam & 0,437109479 & 32,97375 & Mainland General Water Fisheries \\
Belinyu & 1,010866283 & 0,382764823 & Fishing in the Sea \\
Riau Silip & 0,927047207 & 5,14392189 & Mainland General Water Fisheries \\
\hline
\end{tabular}

The following are the results of the analysis of the potential location of the plantation sector based on production indicators, completeness of production PS and the sub-district area that has the most number of leading commodities with a value of $L Q>2$ are inland fisheries (Mendo Barat), inland fisheries (Merawang), inland fisheries (Pudding Besar), inland fisheries (Pemali), inland fisheries (Bakam) and inland fisheries (Riau Silip).

\section{Conclusion}

a. Bangka Regency is one of the areas of the Bangka Belitung Islands province that still has potential because of its abundant wealth, especially in the agricultural, plantation and fishery sectors.

b. Utilization of natural resource processing is still not optimal, so it needs to be handled by the government without destroying the conservation of natural resources. 
c. The development of the agricultural sector supports tourism activities in the Districts of Mendo Barat and Sungailiat, namely agro-tourism and industrial processing activities, both small industries (Sugarliat District) and home industries (Riau Silip District and Pemali District) based on local raw materials, especially regional superior commodities.

d. The plantation sector is the center of production in Sungailiat and Pemali sub-districts with coconut and cocoa commodities. Meanwhile, palm oil processing must be optimized so that it needs to be considered to build an oil palm processing industry in Bakam and Belinyu districts.

e. The Fisheries and Marine Sector are in the Districts of Mendo Barat, Merawang Puding Besar, Pemali, Bakam and Riau Silip. There needs to be a better investment in freshwater cultivation, namely catfish or other freshwater fish which are starting to be in great demand by the people of Bangka, especially immigrants.

\section{Acknowledgment}

This research is a funding grant from the University of Bangka Belitung so we thank the Institute for Research and Community Service (LPPM) of the University of Bangka Belitung and we also thank the Central Bureau of Statistics of Bangka Regency and the Government of Bangka Regency, Bangka Belitung Islands Province.

\section{References}

Article in a Journal:

Economic Assessment of Health Care: Theory and Practice. J. Richardson ... First published: January 1991. https://doi.org/10.1111/i.14678462.1991.tb00378.x.

Kartikaningdyah, Ely. Analisis Location Quotient Dalam Penentuan Produk Unggulan Pada Beberapa Sektor di Kabupaten Lingga Kepulauan Riau Batam

Kohar, Abdul dan Agus Suherman. Analisis Location Quotient (LQ) dalam Penentuan Komoditas Ikan Unggulan Perikanan tangkap Kabupaten Cilacap

\section{Chapter in a Book:}

Arsyad, Lincolin. 2010. Ekonomi Pembangunan, Edisi kelima. Yogyakarta: UPP. STIM YKPM

Glasson, John. 1977 .Pengantar Perencanaan Regional. Fakultas Ekonomi. Universitas Indonesia. Jakarta

Muta'ali, Lutfi, 2015. Teknik Analisis Regional Untuk. Perencanaan Wilayah Tata Ruang dan Lingkungan. Yogyakarta: Badan Penerbit Fakultas Geografi.

Sukirno, Sadono.2010.Makroekonomi, Teori Pengantar.Edisi Ketiga. Jakarta:PT Rajagrafindo Persada.

Tarigan, Robinson. 2007.Ekonomi Regional Teori dan Aplikasi(Edisi Revisi).Jakarta:PT BumiAksara.

Tulus TH Tambunan. (2001). Perekonomian Indonesia: Teori dan Temuan. Empiris. Jakarta: Ghalia Indonesia

Sugiyono. (2017). Metode Penelitian Kuantitatif, Kualitatif, dan R\&D. Bandung : Alfabeta, CV.

Link / URL:

https://babel.bps.go.id/

https://bangkakab.bps.go.id/ 